13p II 4 ¿WE-ド同期レーザーに上万ビコ秒分光

楖田着司(大阪大学・物理)

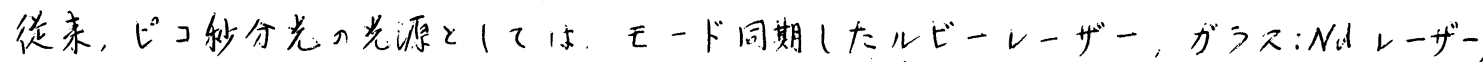

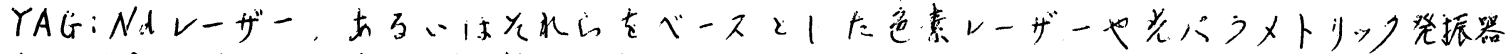

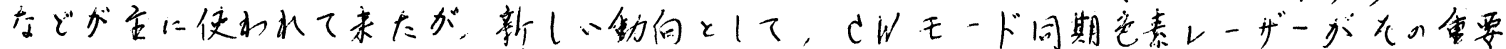

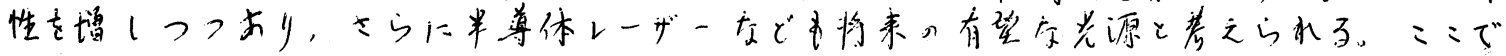

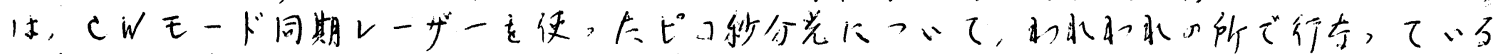
研究去と为含为て速べるこにする。

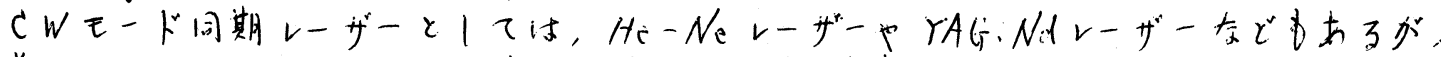

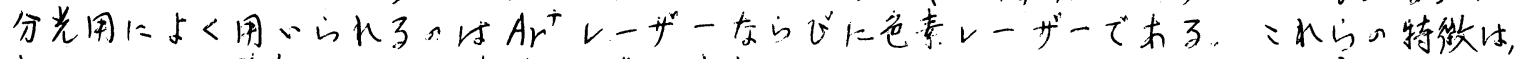

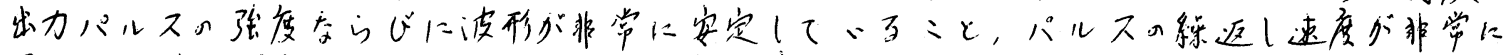

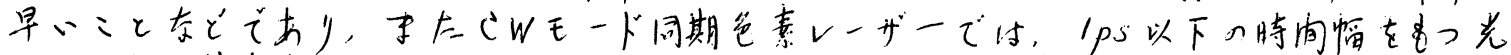

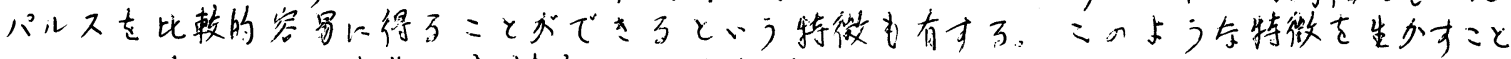
によ”，次のよう会非常上高精度の分光实駼务可能に去万，

光) 二波長レーザー分光

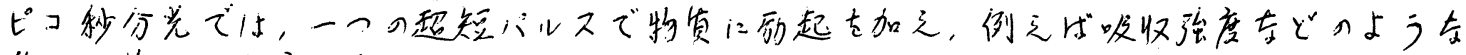
物质の忘答の時间变化を, もう一の超短バル下をプロ一ブといて調べるといた型の实

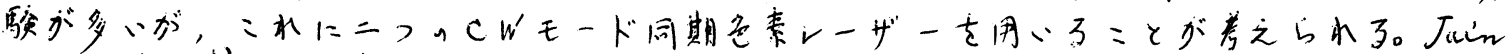

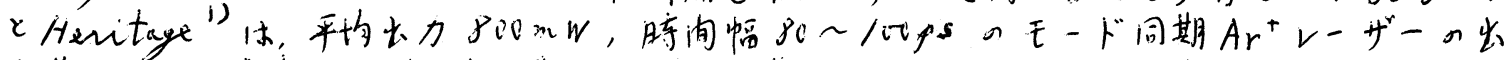

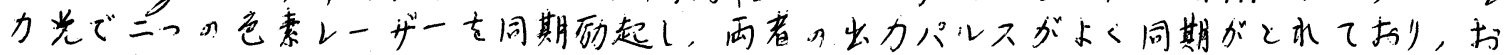

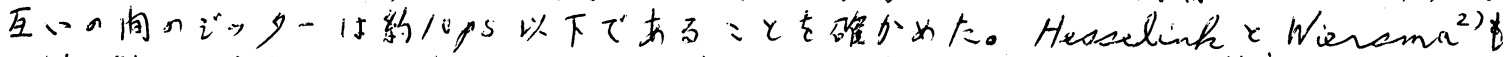

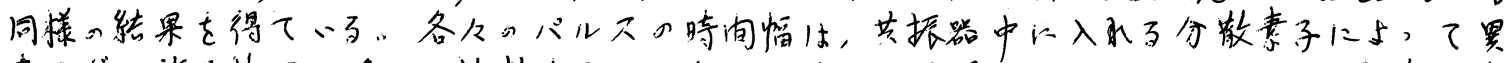

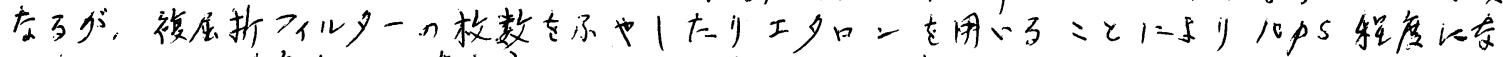

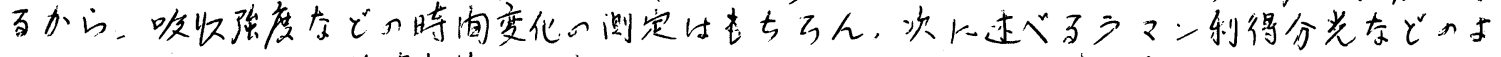

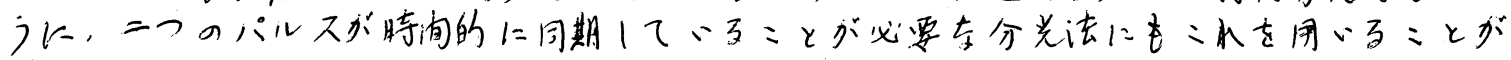
で要。

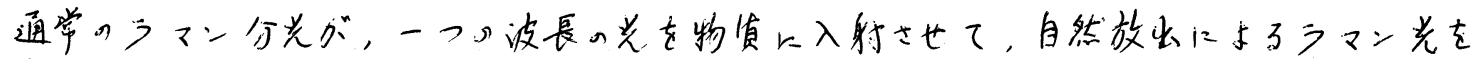
测定するのに对にて、ラマ二利得分光小，励起光とプロ一ブ光の二つの波長の光を入射き

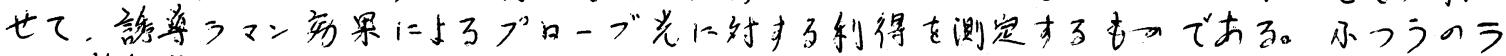

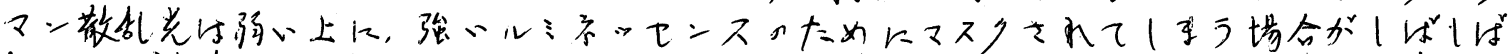

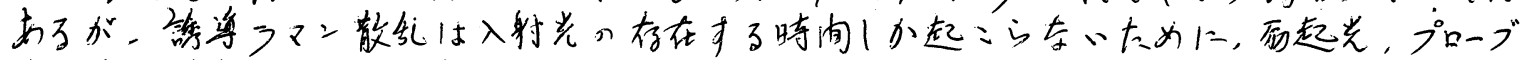

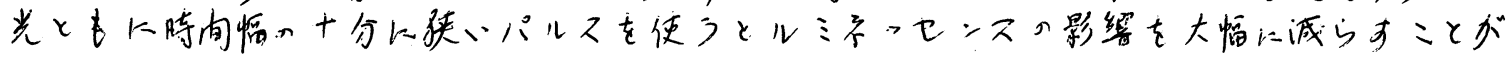
でミ了。

因はは，银表面に吸着(たさNの单分子膜について， うマ一利得分光を行寺, た際。实駼配置を示司。”励起光 を10.7MHzで变調し， 口ックインアンプを用いる、とに

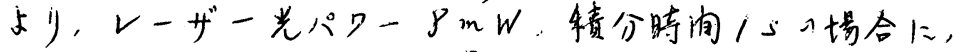

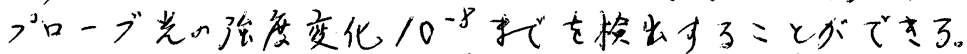

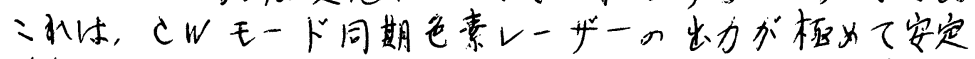
でおろた为で, 金属への吸着によりラマ二散乱断面積加

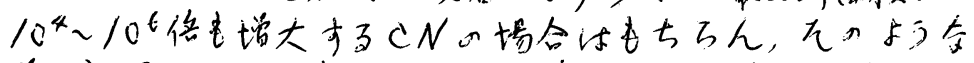

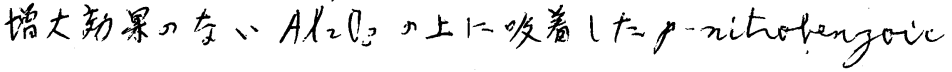

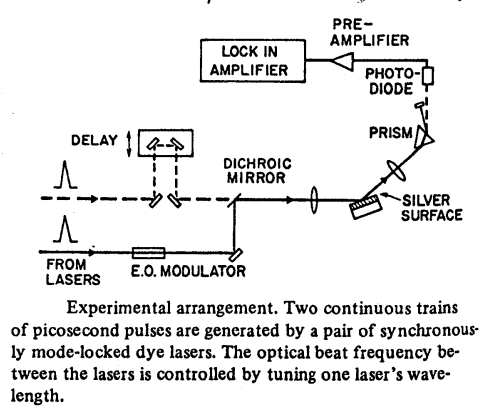

因 1 . 


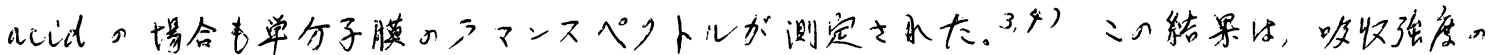

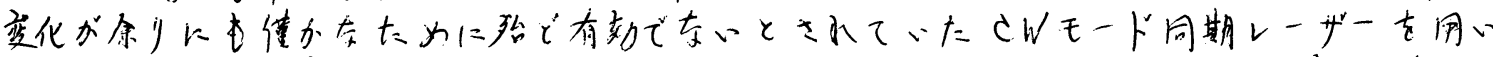

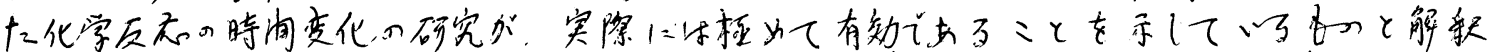

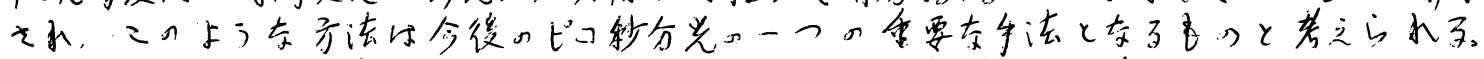

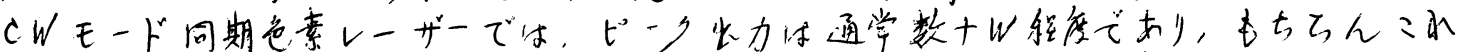

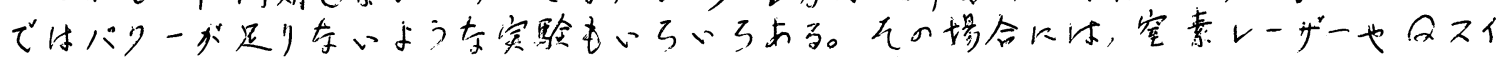

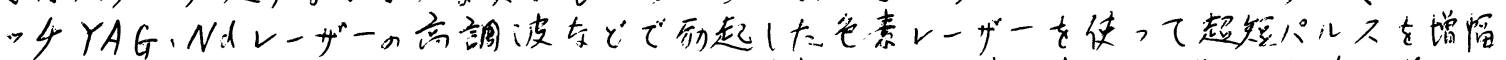

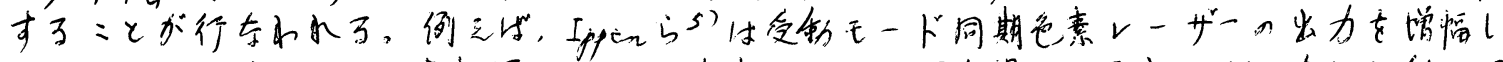

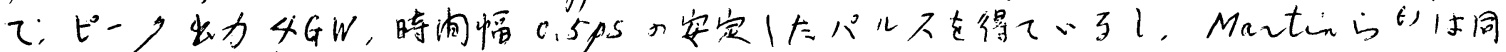

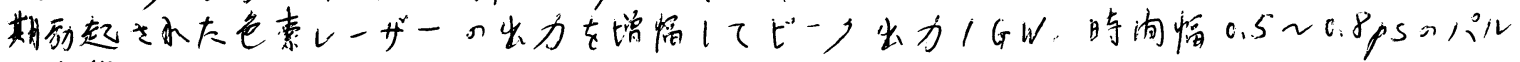
スを得て、る。

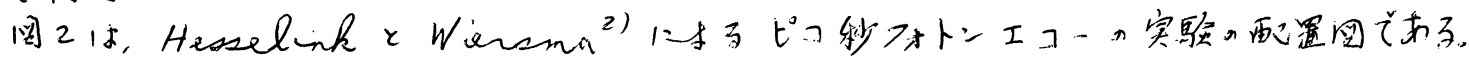

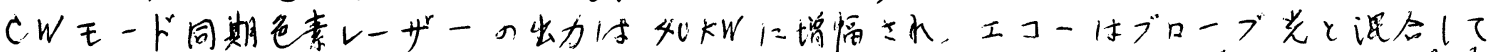

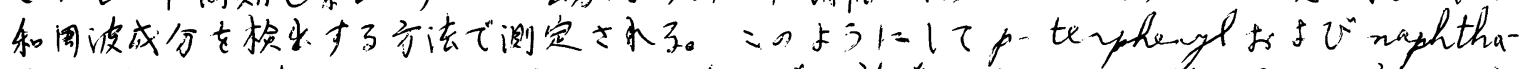

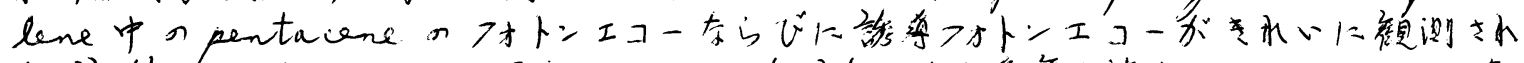

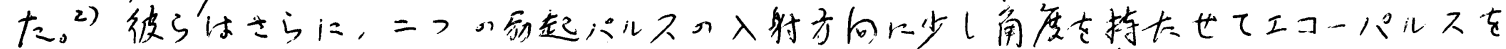

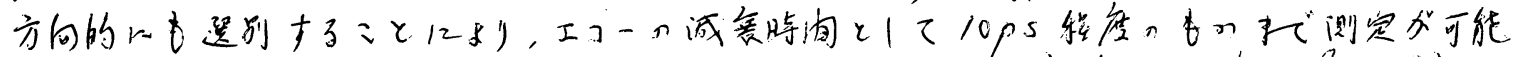

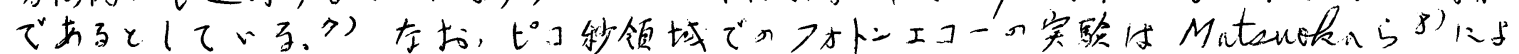

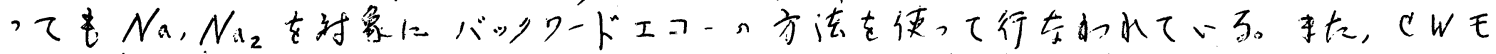

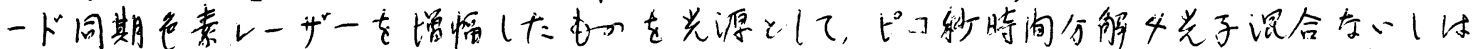

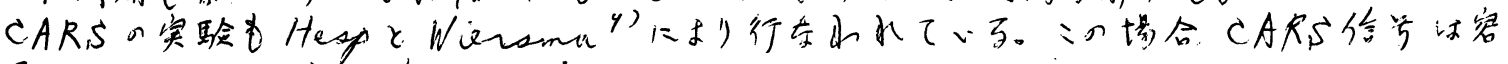
易火目上是之了くらい強いという。

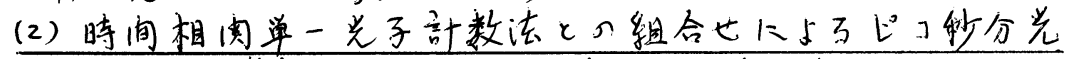

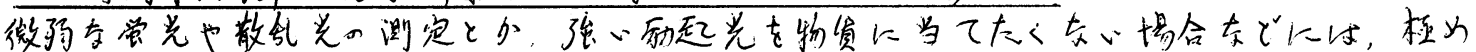

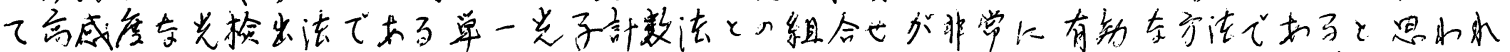

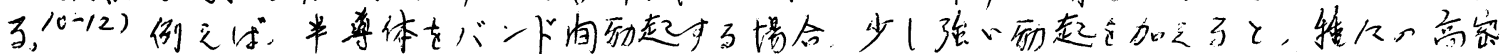

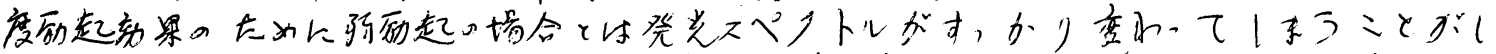

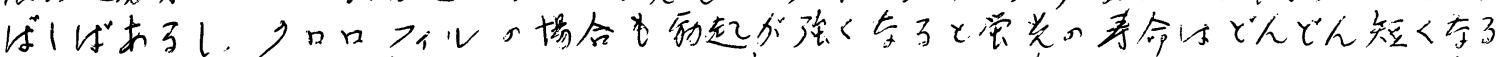

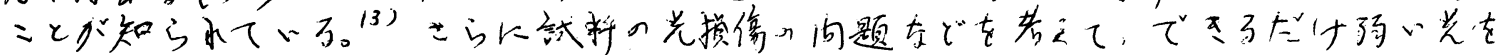

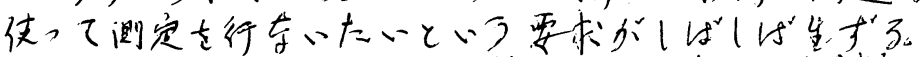

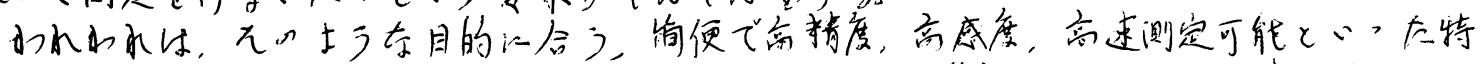

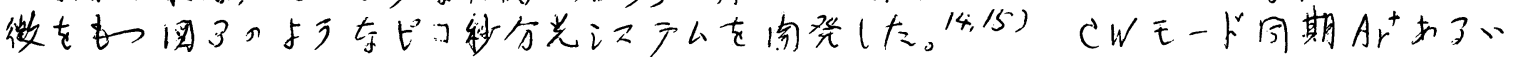
は色素レーザーの出力パルス

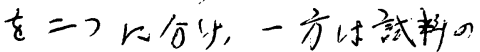

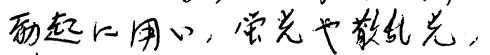
透遏光去它分光(た役，光 雪子增佫管て受甫了。他方向 光はフォト多オードで受け， 增幅。幄延の後, ス卜ワプ只儿 スとに時间一㧓幅变换器

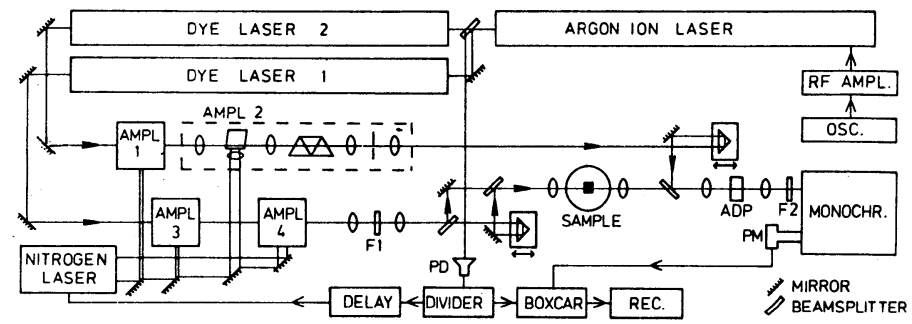
(TAC)に入习了。光電子增 佫管では/個的邪起ハルスに

Experimental arrangement for picosecond photon echo studies. For a detailed description of the set-up consult the text. P. photodiode, PM: photomultiplier, F1: Corning 2-60 filter, F2: Corning 7-54 filter.

用 2 


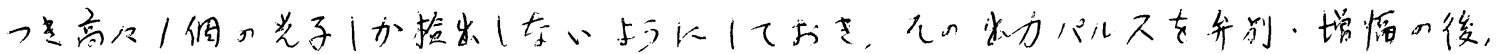

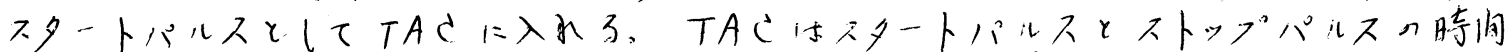

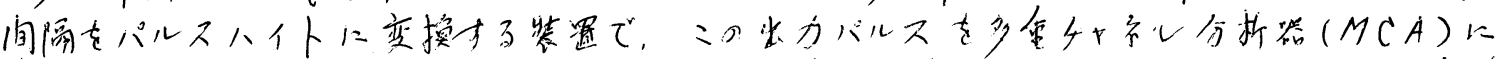

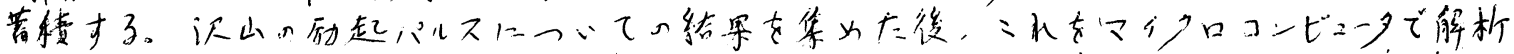

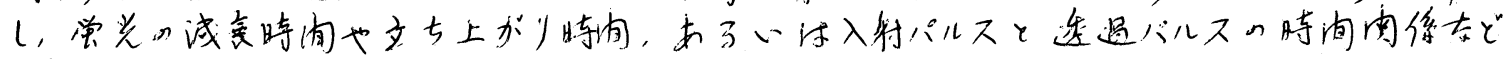
救为了。

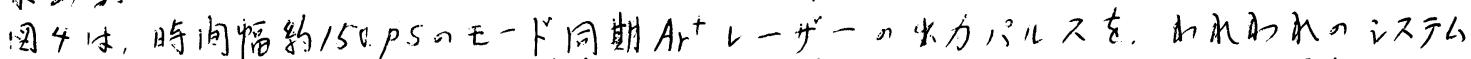

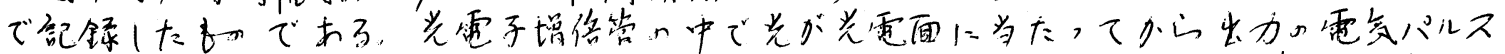

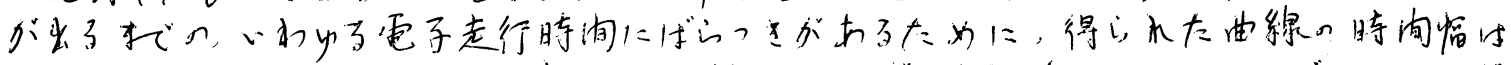

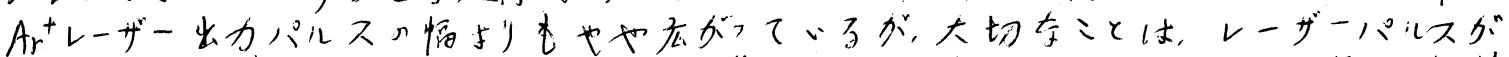

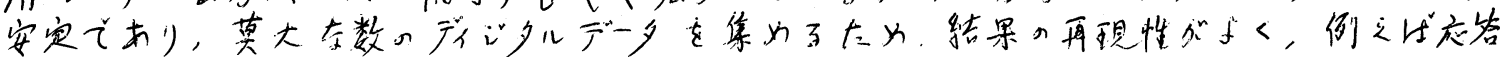

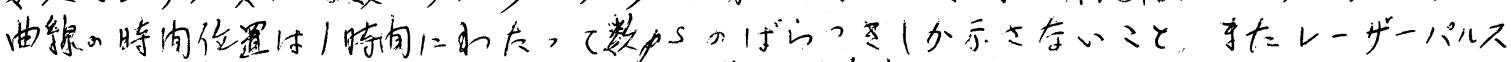

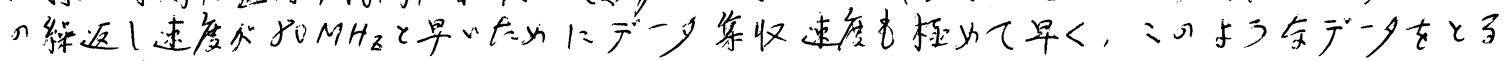

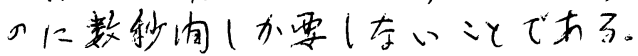

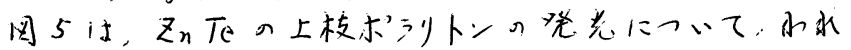

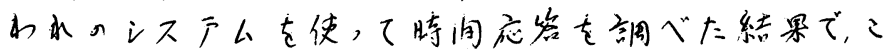

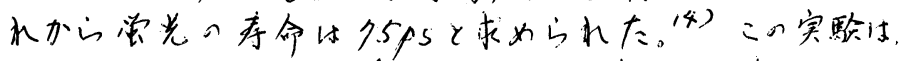

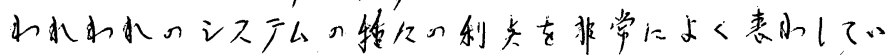

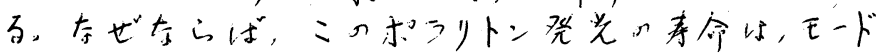
同期YAGiNdレーザーn高調波と光力ーシャッ夕一を用、 ると心たた方法では，前上述へた高密度励起勃果。

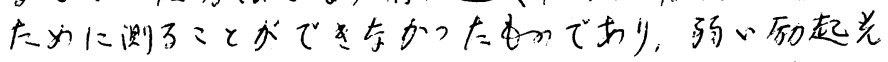

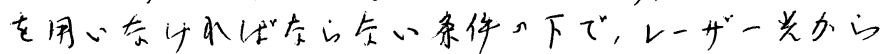

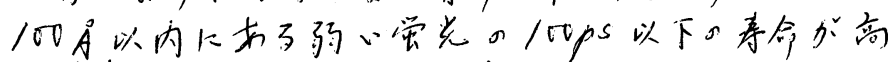

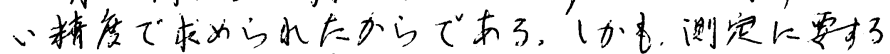

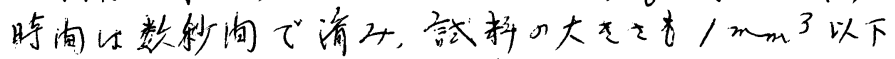

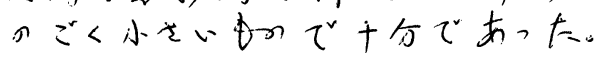

\section{(3) サブピコ秒分光}

サブピコ秒光ハルス小他の方法でも得的水了方， CWモ一ト同期色素レーザーによ万方法加最容

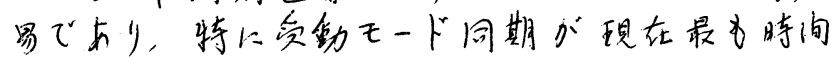

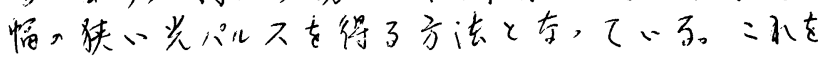

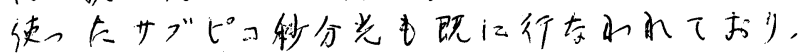

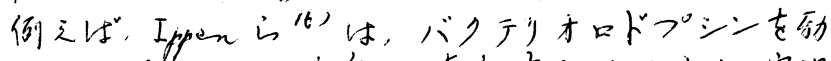
起( た後的吸收強度。時间变化老测定! 富温 で光邪起後约1 p s 几 時定数で新( 以状態加生才

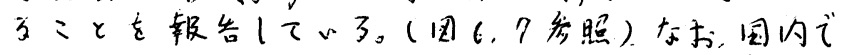

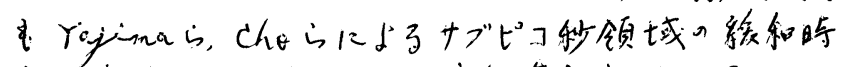

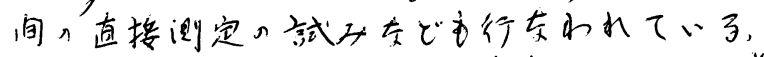

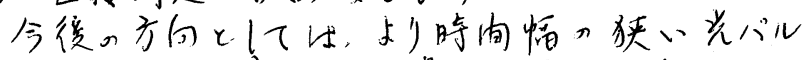

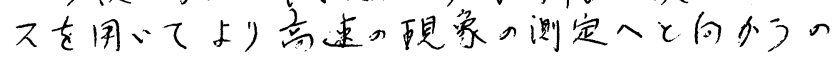
は车ちらんでちらうが、さらに(1)，(2)で述べた
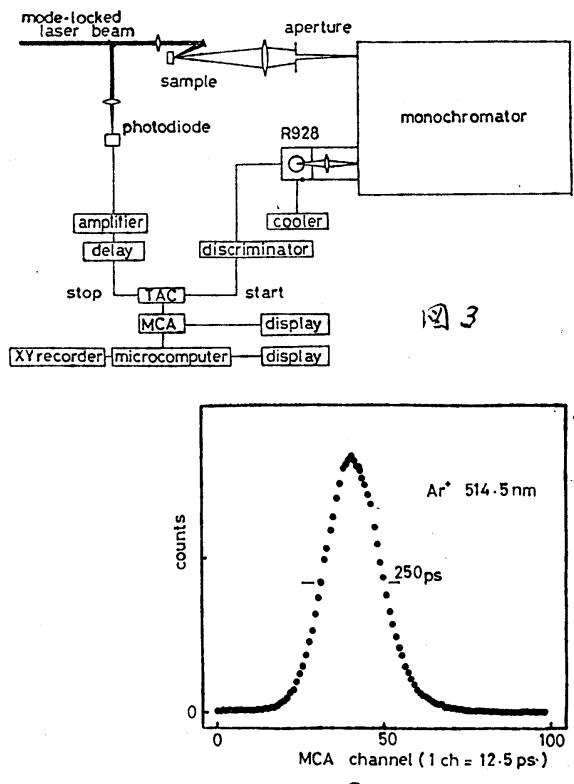

国 4

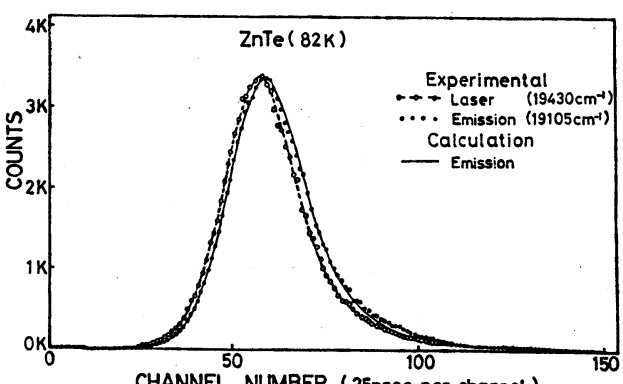

CHANNEL NUMBER (25psec per channel)

团 5

Time behavior of the polariton luminescence
of znje at $19105 \mathrm{~cm}^{-1}$ (closed circles) and

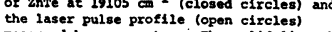
measured by our system. The solid 1 ine shows
the response curve calculated by using the the response curvo calculated by using the
obtanined time behavior of the exciting pulso obtained time behavior of the exciting pas
and the 2 thoorescent decay time of 75 ps. 


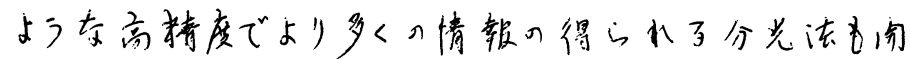

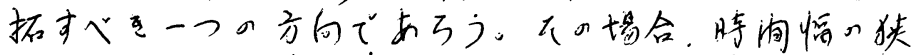
いCWもード同期色素レーザーでニつカ色季レーザーを 同期动起する:とにより，二つのサブビコ秒パルスの间で

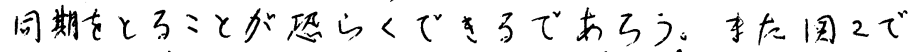

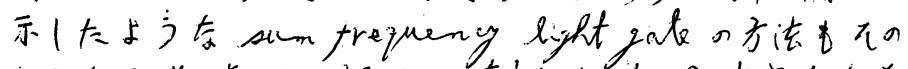

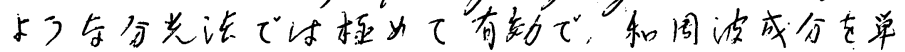

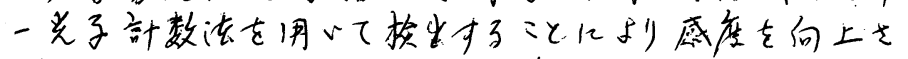

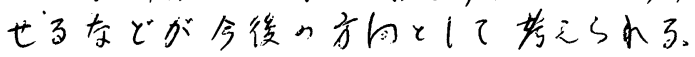

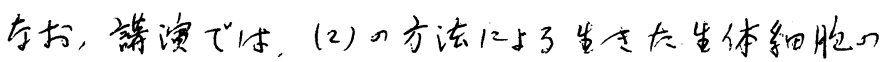

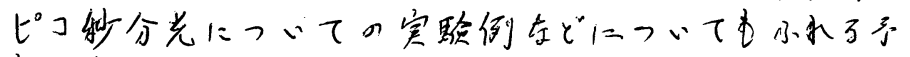
定でちろ。

\section{文献}

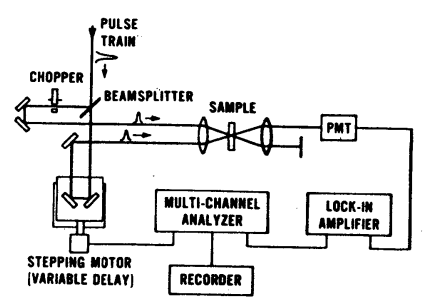

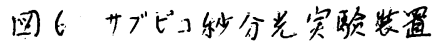

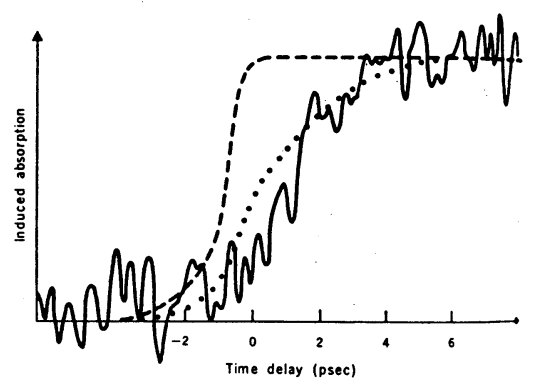

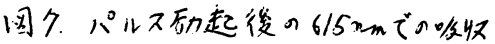

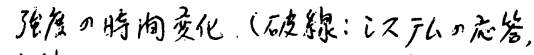

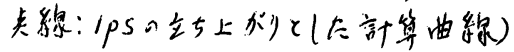

1) R.K.Jain and J.P.Heritage: Appl. Phys. Lett. $\underline{32}$ (1978) 41 .

2) W.H.Hesselink and D.A.Wiersma: Chem. Phys. Lett. $\underline{56}$ (1978) 227; J. Chem. Phys. $\underline{73}$ (1980) 648.

3) J.P.Heritage, J.G.Bergman, A.Pinczuk and J.M.Worlock: Chem. Phys. Lett. 67 (1979) 229.

4) J.P.Heritage and D.L.Allara: Chem. Phys. Lett. $\underline{74}$ (1980) 507.

5) E.P.Ippen and C.V.Shank: Picosecond Phenomena, ed. by C.V.Shank, E.P.Ippen and S.L.Shapiro (Springer-Verlag 1978) p.103.

6) J.L.Martin, R.Astier, A.Antonetti, C.A.Minard and A.Orszag: C. R. Acad. Sci. Paris $t 289$ (1979) 45 .

7) W.H.Hesselink and D.A.Wiersma: Chem. Phys. Lett. 65 (1979) 300.

8) M.Matsuoka, H.Nakatsuka and M.Fujita: Picosecond Phenomena II (Springer, 1980) P.357.

9) B.H.Hesp and D.A.Wiersma: Chem. Phys. Lett. $\underline{75}$ (1980) 423.

10) K.G.Spears, L.E.Cramer and L.D.Hoffland: Rev. Sci. Instr. 49 (1978) 255.

11) V.J.Koester and R.M.Dowben: Rev. Sci. Instr. $\underline{49}$ (1978) 1186.

12) K.P.Ghiggino, A.J.Roberts and D.Phillips: J. Phys. E 13 (1980) 446.

13) A.J.Campillo, V.H.Kollman and S.L.Shapiro: Science 193 (1976) 227.

14) T.Kushida, S.Kinoshita, H.Ohta and T.Morie: Solid State Commun. 35 (1980) 267.

15) S.Kinoshita, H.Ohta and T.Kushida: (to be published in Rev. Sci. Instr.)

16) E.P.Ippen, C.V.Shank, A.Lewis and M.A.Marcus: Science 200 (1978) 1279. 